\title{
INTRODUCING THE THEMES
}

\author{
José E Alvarez*
}

The call for papers that yielded the fascinating essays collected in this journal explained the interest in this subject as arising from the confluence of two facts: the increase in the number of countries around the world now governed by some form of "democracy" and the rising levels of international forms of regulation that purport to affect a broad range of issues within such nations. The call for papers suggested that these two developments made it "inevitable" that international lawyers should now be addressing whether international law and institutions are "democratic." The first fact is put in concrete terms in the opening sentences of Craig Forcese's contribution, in which he indicates the substantial increase in the percentage of the world's peoples living in electoral democracies since the end of the Cold War. The second development is ably demonstrated by the range of subject matter canvassed by this symposium. Contemporary international law's widening normative aspirations are suggested by the essays in this symposium, which address not only the traditional topics of war and peace, national security, or refugee status but include topics once regarded as within the exclusive "domestic jurisdiction" of states - such as decisions to preserve historic sites, to engage in environmental decision-making, how best to respect the rights of minorities, women, or homosexuals, or even interpret one's national constitution.

While the impetus for this symposium is the perceived "democratic" gap between national and international forms of law-making, its organisers did not presume that democracies were more likely to comply with international law than other regimes. Our premise was only that democratic polities were generating greater (or at least more public) forms of backlash against ever more intrusive forms of international law. The call for papers suggested that democratic societies "are more apt to question whether international legal obligations, both treaty based or customary, are sufficiently 'accountable' or 'transparent."' The starting proposition was that international law was increasingly seen as "vertically challenged," that is, subject to various forms of "democratic deficits" as compared to democratic law-making "below" it at the national level.

\section{THREE TYPES OF "VERTICAL" COMPLAINT}

As a number of the contributors point out, the most common definition of democracy focuses on governance through elected representatives, or majority rule. Accordingly, the most common "democratic" complaint lodged against international law-making processes is that since there is no

* Hamilton Fish Professor of Law \& Diplomacy, Columbia Law School. 
international parliament subject to proportional representation of the peoples of the world, international law-makers lack the ties to democratically elected polities that legitimise law within democracies. The United Nations (UN) General Assembly, subject to one state/one vote, is a far cry from meaningful democratic representation and, notwithstanding the hopes of some scholars, the prospect of a global parliament subject to proportional representation does not seem a likely prospect (even assuming we find a big enough coliseum to house it). ${ }^{1}$ Nor do international lawmaking processes, whether within formal international organisations (IOs) such as the UN or the World Trade Organization (WTO) or outside of them (as in transnational networks of regulators) appear to enjoy the other structural components associated with representative electoral polities such as checks and balances between legislative, executive and judicial branches or conceptions of "separation of powers" (as in the United States legal system) among these actors. ${ }^{2}$

This kind of "democratic" critique is frequently directed at the emerging "case law" of international dispute settlers, even when these are relied upon by national judges. The views and opinions issued by adjudicators as different as those within international criminal tribunals or human rights treaty bodies are putting a new spin on the old "counter-majoritarian difficulty" that many have long argued undermines the legitimacy of national judges within democracies. The attack on international judicial law-makers (and those who cite them) is all the more severe because of the perception that unlike national judges, whose law-making prowess might be checked by executive agencies or legislatures, such "checks" rarely exist at the international level, not even in the most institutionalised global regimes, such as the WTO.

International adjudicators are not the only ones who are seen to be "vertically challenged." As Craig Forcese's essay on the UN Security Council reminds us, the rare forms of international "legislation" that exist may undermine constitutional separation of powers principles within democracies. As Forcese points out, when Security Council fiat is implemented at the national level through executive branch fiat, the power of national executives threaten to become as unbounded and un-checkable as is the Security Council itself. The very nature of international law makes it susceptible to "democratic" complaints. A law that is so firmly grounded in the principle of formal equality between co-equal sovereigns, and that seemingly makes no distinctions between "democratic" and "authoritarian" states, makes for an all too easy target, even when the underlying "democratic" difficulties might be correctable at the national level (as by controlling executive discretion to enforce international law). International regimes subject to universal membership,

1 Compare Richard Falk and Andrew Strauss "Toward Global Parliament" (2001) Jan/Feb Foreign Aff 21 with Robert A Dahl "Can International Organizations Be Democratic? A Skeptic's View" in Ian Shapiro and Casian Hacker-Cordón (eds) Democracy's Edges (Cambridge University Press, New York, 1999) 19.

2 But see Ruth W Grant and Robert O Keohane "Accountability and Abuses of Power in World Politics" IILJ Working Paper 2004/7 at www.iilj.org (accessed 25 May 2007) (suggesting alternative ways that some international regimes achieve checks and balances). 
whose legal products are produced by processes that include the active participation of governments that are not elected by their citizens, appear to many to be inherently "undemocratic." Organs like the UN General Assembly, which purport to affect if not make international law in a number of ways, do not enjoy democratic legitimacy to make law for anyone, least of all the democratic members of the Assembly.

But democracy need not be measured by electoral representation or resulting principles of separation of powers. For those with a more Habermasian outlook, international law-making processes get into trouble when that they lack the participatory forms of deliberation associated with democratic forms of governance. This is the democratic tradition highlighted by Jacqueline Peel's "proceduralist" tradition, Neil Craik's reference to "deliberative democracy," or the notion of "polyarchy" that Teraya Koji reminds us is associated with Robert Dahl (a conflation of public contestation and the right to participate). For those who focus on the merits of deliberation, international law's "democratic" deficits emerge when its law-making processes lack transparency and/or broad public participation, or, as Craig Forcese suggests, when international fora affirmatively exclude such forms of participation or privilege the least transparent organs within democracies, such as the executive branch.

Participation or deliberation gaps tend to be the focus of those who see international law-making processes through an administrative law lens - such as Benedict Kingsbury and his colleagues at NYU. ${ }^{3}$ Yet, as is suggested by some of the contributors here, all else being equal, seeing international law's "democratic" deficit as flaws in deliberative processes is more attractive to international lawyers since this gap is subject to simpler remedies than are representational deficiencies.

The third "democratic" deficit is substantive, not procedural. For some democratic critics, problems emerge when international law-making processes fail to respect the substantive rights associated with democratic governance, such as the due process rights owed to individuals or their rights not to be subject to ex post facto criminal law. As Craig Forcese suggests in his criticism of Security Council sanctions that are functionally the equivalent of a criminal penalty without benefit of trial, a liberal democracy worthy of the name is one that preserves rights and liberties and adheres to the rule of law. This is the very antithesis of a UN Security Council that passes the equivalent of a bill of attainder with direct impact on sanctioned individuals. This complaint also motivates, for example, the critics of World Heritage designations discussed by Natasha Affolder who would argue that regimes that deprive individuals of their rights to develop property adjacent to heritage sites without sufficient process are demonstrably illegitimate.

3 See for example Benedict Kingsbury, Nico Krisch and Richard B Stewart "The Emergence of Global Administrative Law" (2005) 68 Law and Contemp Probs 15. 
Substantive critiques of international law may emerge from all points on the political spectrum. Although many of the complaints against international regimes stress the challenge they present to respecting civil and political rights associated with democratic societies, some critics focus on their failings with respect to broad economic, social and cultural rights, including those formally proclaimed in (but rarely enforced under) the International Covenant on Economic, Social and Cultural Rights (ICESCR) or the Convention on the Elimination of All Forms of Discrimination Against Women (CEDAW). For those on the left, problems emerge when international law-making processes - such as those associated with WTO dispute settlement, IMF structural adjustment loans, or World Bank decisions on infrastructure projects - fail to respect "democratic" demands that such rights be respected or that effective mechanisms be implemented to enforce them at the international level, even as against IOs themselves. ${ }^{4}$

\section{HORIZONTAL COMPLAINTS}

As Koji Teraya points out in his essay, contentions that there is a "vertical" disconnect between the international and the national rule of law need to be distinguished from critiques about the absence of "democratisation as between states." The latter asserts that international law-making is illegitimate to the extent it fails to treat sovereigns as horizontal equals. Despite its rhetorical respect for "sovereign equality," the UN Charter, after all, gives the Permanent Five elevated rights to legislate in the Security Council, and some of that legislation fails to respect the rights of both individuals and sovereigns to equal treatment. Similarly, the international financial institutions accord privileged status to those who hold their purse-strings - states that, of course, are never subject themselves to their strictures (such as IMF conditionality). As Jacqueline Peel's paper suggests, international law-making processes dependent on independent expertise or that grant access to prominent members of "international civil society" may be perceived to exacerbate inequalities among states, precisely because not all governments have access to comparable levels of expertise or are host to NGOs able to defend their environmental (or other national) laws against outside interference.

As this suggests, international regimes' reliance on "international civil society" to blunt the force of one of the "democratic" critiques - by enhancing forms of participation - runs the risk of exacerbating horizontal critiques. Even those institutions established to "level the playing field" between rich and poor through recourse to impartial dispute settlement less dependent on diplomatic leverage among unequal states, such as the WTO, are now subject to second order criticisms - as from those who contend that some WTO members have privileged access to dispute settlement and,

4 This appears to motivate efforts such as the International Law Commission's current project to promulgate rules of IO responsibility corresponding to those it promulgated with respect to states. For texts of the draft articles of responsibility of international organizations as adopted by the ILC's drafting committee through July 2006, see UN documents A/CN.4/L.632, A/CN4/L.648, A/CN.4/L.666/Rev1， A/CN4/L.687, A/CN.4/L.687/Add.1 (containing articles 1-30). 
given the realities of trade, unequal leverage with respect to enforcing WTO decisions through tariff retaliation. As this last point suggests, some of the horizontal complaints directed at international law-making are directed less at its forms of law-making than at its unequal forms of enforcement. No one claims that a state like Paraguay is as free to ignore a ruling by the International Court of Justice, the WTO, or a human rights body, than is the United States. From this standpoint, it is the continued weakness, not its robustness, of international forms of law-making that promotes perceptions of illegitimacy.

\section{IDEOLOGICAL CRITIQUES}

International forms of law-making, whether the actions of Western-dominated actors such as the International Monetary Fund or of like-minded technocrats (such as the experts making site determinations in the World Heritage regime or the central bankers of the Basel Committee) are also criticized for reflecting the dominant ideology (cultural, political, gender-based, or otherwise) of Western governmental elites. As Susan Marks (among many others) have argued, even "objective" international law reflects ideological preferences in favour of, for example, the market, "scientific" expertise, deregulation, or civil/political rights (over social or economic rights). ${ }^{5}$ Such ideological critiques may be hard to disentangle from horizontal and vertical complaints. Craig Forcese's criticism of some Security Council actions as a form of "hegemonic federalism" or Jacqueline Peel's critical view of the delimited approach to expertise taken in some WTO cases, for example, might be said to rely on all three forms of critique.

But these diverse critiques - the three forms of vertical critique or the horizontal or ideological ones - do not always point in one direction and may suggest inconsistent remedies. The vertical and horizontal critiques against international law can point in opposite directions since, as suggested, international law-making processes that respect sovereign equality by giving each state an equal vote are, by definition, out of sync with the proportional voting schemes that the first "vertical" critique presumes is the very essence of democratic governance. Yet, some forms of vertical and horizontal critique converge in practice since, after all, when some states' views do not count as much as others, their democratic constituencies suffer as well.

All of this leaves modern international lawyers in something of a bind. Possible solutions to perceived horizontal inequalities - such as a more robust institutionalised dispute settlement scheme that is equally accessible to all states - may exacerbate perceived vertical "democratic" deficits, at least to the extent such a remedy solidifies the power of a supranational judiciary whose adjudicators may be less accountable to democratic polities than are national judges. This is certainly one lesson of those who, frustrated with weak enforcement in human rights treaty bodies, have looked with penance-envy on the WTO dispute settlement scheme - only to discover that

5 Susan Marks The Riddle of All Constitutions: International law, Democracy, and The Critique of Ideology (Oxford University Press, New York, 2003). 
expanding the jurisdiction of that regime may be detrimental to achieving their substantive welfare goals. It is also the lesson that foreign investment lawyers are discovering. While many would like to fix a fractured investment regime whose ad hoc rulings threaten horizontal equity as between states, others are more fearful of the proposed obvious remedy, namely a investment appellate mechanism comparable to the WTO Appellate Body since such an entity, like the WTO's, will inevitably become the target of vertical critiques. Modern international lawyers, like some trade lawyers, are no longer as confident as they once were that global welfare will invariably be enhanced by empowering more individuals to think of themselves as supranational judges.

Believers in international law are also torn - given the inconsistencies among these critiques about whether it would "enhance" democracy to turn to non-governmental alternatives to more traditional inter-state rule-making. As Affolder warns, turning to private initiatives to define global rules for natural resource extraction - processes that are even less open, inclusive or democratic than those within inter-governmental regimes - may not enhance democracy.

Most often, the vocal critics of international law-making or its institutions - whether on the streets of Doha against trade rounds or in Washington directed at the IMF - are not aware that they are lodging inconsistent forms of critiques against international law, including divergent conceptions of "democracy." Many do not even notice that they hold diametrically opposing views of the value of principles such as "sovereign equality."

\section{THE CRITIQUES IN INSTITUTIONAL FORM}

These critiques take distinct institutional form and are often directed at traditional IOs created since WWII. ${ }^{6}$ Their perceived vertical/horizontal/and/or ideological flaws undermine the structural elements of these institutions and there is now something of a backlash against the Grotian consensus that produced such organisations. ${ }^{7}$ As is suggested by the move from the discredited UN Human Rights Commission to the less universalistic Human Rights Council or the turn to regional alternatives in a variety of contexts (from security to trade), there is some scepticism about the merits of the universalism on which the UN system was constructed. Some are also concerned about the "proliferation" of IOs, including forms for institutionalised dispute settlement. We worry about the law-making prowess of international adjudicators, the risk of fracture to the international rule of law through inconsistent rulings, the privilege conferred by such forums on "Western" contentious approaches to settling disputes (and attendant benefits conferred on United States and European lawyers as one result), or the attendant possibilities for forum shopping (and potential benefits conferred on richer states that can best take advantage of such options).

6 See, for example, José E Alvarez "International Organizations: Then and Now" (2006) 100 Am J Int'l L 324.

7 See, for example, ibid; see also "The Move from Institutions?" (Proceedings of the $100^{\text {th }}$ Annual Meeting of the American Society of International Law, 2006) 287. 
In some cases, especially with respect to international criminal courts, we are increasingly concerned about the distance between those doing the judging and the societies whose perpetrators are being judged. We are not as confident as we once were that internationalised dispute settlement at some distance from the local can support equally both the national and international rule of law, much less achieve the myriad grand goals associated with Nuremberg - from preserving accurate collective memory to achieving justice for victims of mass atrocities. As Jacqueline Peel's essay suggests, these concerns extend beyond international criminal law as even WTO adjudicators face challenges about the deference they owe to national agencies applying their expertise.

Scholars, policy-makers, and even voting publics of many states in Europe (who voted against the proposed EU constitution), are now exhibiting scepticism about the value of elevating institutional charters to the status of some kind of "constitution," whether for the UN or for the WTO. ${ }^{8}$ International lawyers are not as certain as they once were that broad, teleological interpretations of instruments such as the UN Charter or the IMF Articles of Agreement are normatively desirable or consistent with improving global welfare. Today's Grotians are no longer sure that delegating ever more power to international civil servants (or experts or judges) through organisational charters or treaties according implied powers are always consistent with either the goals of sovereigns or the international community.

As is suggested here by the essays by Peel and Affolder, Grotian faith in the "scientific codification" of the international rule of law through resort to apolitical technical experts in innumerable subfields is being tested. Faith in permanent venues for international technocratic discourse has been undermined by post-modern critical scrutiny of who engages in that discourse and for what purpose. As these essays suggest, expertise - whether of the legal or the scientific kind - includes choices among politically contested values.

Not a single aspect of the Grotian consensus that contributed to the $20^{\text {th }}$ century's "move to institutions" has escaped unscathed. ${ }^{9}$ The second generation of international lawyers, who were not present at the creation and less personally invested in the success of these institutions, are reexamining whether compliance through institutionalised socialisation is really a good thing; whether the law produced by the institutionalised interaction of state (and sub-state actors), NGOs, independent civil servants, and experts is really politically or economically or culturally "neutral;" whether the codification of international law really can be characterised as innovative, progressive achievements.

8 For a survey of the arguments for and against conceptions of "constitutionalism" within the WTO, see Deborah Z Cass The Constitutionalization of the World Trade Organization (New York, Oxford University Press, 2005).

9 Compare David Kennedy "The Move to Institutions" (1987) 8 Cardozo L Rev 841 to Alvarez, above n 7. 


\section{THE CRITIQUES AND ARTICLE 38 SOURCES}

The complaints against modern international law-making are also directed at the sources of contemporary international law. As is suggested by some of the essays in this symposium, even that source of international obligation that appears most dependent on explicit sovereign consent (and in principle, most immune from "democratic" complaint), namely the treaty, does not escape criticism. Some now worry about substantive provisions contained in contemporary multilateral agreements because the underlying negotiations are not transparent or subject to genuine legislative scrutiny; because some treaties (such as the Landmines Convention or the Rome Statute for the International Criminal Court) may cede too much voice to non-state actors (from NGOs to the UN secretariat) and dilute the voice of representative states; because some agreements may not be subject to legislative or parliamentary approval but are entered into solely by the executive fiat (as are executive agreements in the United States); because in other cases, these agreements may have be considered only by one house of a bicameral legislature (as is the case with respect to Article II treaties in the United States which are, unlike those subject to "fast track" authority, subject only to Senate concurrence to ratification); because, whether or not originally subject to Congressional or parliamentary consent, contemporary treaties that expressly or implicitly delegate authority to institutional organs, private parties, or dispute settlers are no longer subject to continuing democratic scrutiny and consent even though their interpretation is subject to change over time; because modern "legislative" treaties (such as human rights instruments) are often treated as establishing customary law, binding even with respect to non-ratifying states; or because some treaties (such as environmental framework conventions) may license institutional processes (such as Committees or Meetings of the Parties) empowered to modify states' commitments through a less than unanimous vote. Neil Craik's essay attempts to answer some of these critiques.

Nor have bilateral treaties escaped adverse scrutiny. Critiques of the "horizontal" difficulties with many bilateral treaties - where the leverage of powerful states is at its greatest ebb - are manifest with respect to, for example, United States' "Article 98" agreements that purport to exclude United States nationals from the jurisdiction of the International Criminal Court or bilateral investment treaties alleged to be contrary to the real long term interests of some developing countries. ${ }^{10}$ In these cases, it is not hard to transmute an underlying worry about how international law "launders" power into a concern about how treaty-contracts undermine the will of democratic polities in less powerful states.

Of course, as those familiar with a considerable amount of "revisionist" scholarship within the United States know, contemporary forms of customary international law has not escaped the scrutiny of international law's "democratic" critics. Given the scrutiny now accorded to

10 See, for example, David Scheffer "Article 98(2) of the Rome Statute: America's Original Intent" (2005) 3 J Int'l Crim J 333; Andrew Guzman "Why LDCs Sign Treaties that Hurt Them: Explaining the Popularity of Bilateral Investment Treaties (1998) 38 Va J Int'l L 639. 
contemporary treaties, it is not unexpected that customary international law - which today often emerges alongside modern "legislative" treaties - should also excite critical interest. As is suggested by Melissa Waters' essay, to the extent custom (or for that matter general principles of law drawn from comparing the municipal codes of nations) are used by national courts, resort by the "least democratic branch" to this source of law generates "democratic" concerns. Nicole Roughan's and Joanna Harrington's respective essays attempt to answer some of the concerns associated with contemporary customary law.

\section{THE CRITIQUE OF MODERN LAW-MAKING ACTORS}

Vertical/horizontal/ideological problems also focus renewed attention on the legitimacy of contemporary law-making actors. Critics of international law sometimes blame the hegemonic super-power, whose exceptionalism has arguably been responsible for some of the more problematic recent developments, such as the legislative turn by the Security Council or inequities associated with institutionalised dispute settlement (such as forum shopping). Others have blamed, at least in part, "special interest" NGOs, whose activism might be blamed for developments as varied as allegedly "ineffective" human rights treaty compliance mechanisms or other "feel good" multilateral agreements containing lowest-common-denominator, and therefore meaningless, substantive provisions. Some blame authoritarian governments, whose cynical participation in treaties that they have no intention of complying with have undermined the credibility of all of international law.

Criticism might also be levelled against the splintering of the state and such "undemocratic" phenomena as transnational networks of sub-government actors, from central bankers to food manufacturers, or other forms of expert-generated law. ${ }^{11}$ The perceived "democratic deficit" applies with full force to ostensibly "soft" regulation that such actors encourage since soft law usually emerges and may even be enforced (as through WTO dispute settlement interpreting the Sanitary and Phytosanitary Measures (SPS) Agreement) without benefit of the traditional checks associated with "hard law" sources like treaty or custom subject to at least some form of state consent. ${ }^{12}$

As Melissa Water's essay implies, it is also easy to pin the blame for "democratic" flaws on our growing transnational judiciaries, including those national judges who have revived fears of the counter-majoritorian difficulty by conflating the interpretation of constitutions with the interpretation of statutes.

While the essays in this symposium canvass these complaints across an extraordinary range of regimes, they do not begin to canvass all the pockets in international law where these issues arise.

11 See, for example, Kenneth Anderson "Squaring the Circle? Reconciling Sovereignty and Global Governance Through Global Government Networks" (2005) 118 Harv L Rev 1255.

12 Ibid. 
The essays in this symposium emphasise some matters (such human rights) at the expense of other topics (such as international economic law or "private" international law). Although the WTO is addressed in one essay, the contributions here do not canvass numerous other subjects of WTO law - apart from the SPS agreement - where arguable "democratic" or "accountability" problems arise. Moreover, the entire foreign investment regime - including the increasingly numerous decisions emerging from International Centre for the Settlement of Investment Disputes arbitrators under bilateral investment treaties or the NAFTA - is not considered by our contributors. The alleged vertical/horizontal/and ideological gaps in that regime are becoming a huge political issue and have even prompted changes in more recent United States and Canadian investment treaties (which cut back on the rights these regimes have previously accorded their own investors abroad given fears that these governments appear to have with respect to their own prospects for liability). ${ }^{13}$ Complaints against that regime are particularly prominent with respect to states like Argentina. As is suggested by the defences to liability presented to date in investor-state disputes by Argentina, Argentine officials complain that their populations were made to suffer indignities and worse thanks to an economic crisis allegedly tied to the investment and other economic policies imposed by the IMF. ${ }^{14}$ For these officials, the sting imposed by international law and institutions appears particularly grave. They argue that they - and the Argentine public - are being doubly victimised by being forced to pay compensation to foreign investors injured by that state's reactions to an economic crisis allegedly not of the government's making who can now bring directly enforceable arbitral claims against their government host.

The investment regime raises most prominently a complaint against one form of international dispute settlement - those open to complaints by individuals and not just states - that is only tangentially addressed in this symposium. While international lawyers have tended to assume that opening international dispute settlement to individuals - as in the EU and in regional human rights courts - is desirable since it will only enhance the reach and effectiveness of international norms, that foreign investors are now accorded the right to be their own private attorneys general in charge of enforcing over 2000 investment agreements is no longer seen with equanimity - even by some of the governments most initially enthusiastic about international investment protections. Indeed, this is one reason why the defence of sovereignty - and of governments as the bulwark for defending the welfare rights of their polities against overweening supranational law- is staging a comeback, including by some liberal defenders of internationalism such as Benedict Kingsbury. ${ }^{15}$

13 See latest United States Model Bilateral Investment Agreement at www.state.gov (accessed 25 May 2007); for Canada's, see www.international.gc.ca (accessed 25 May 2007).

14 See, for example, $L G \& E$ Energy Corp and Argentine Republic (Decision on Liability) (3 October 2006) ICSID Case No ARB/02/1.

15 Benedict Kingsbury "Sovereignty and Inequality" (1998) 9 EJIL 599. 


\section{THE VIRTUES OF "COMPARATIVE INTERNATIONAL LAW"}

One of the delights of this symposium is that the young scholars who responded to the call for papers do not attempt to rehash the vertical/horizontal/ideological critiques surveyed above. In some cases, they attempt to answer such critiques with interesting defences of the Grotian enterprise, including its institutions and sources of obligation. In other instances, the contributors implicitly challenge the underlying assumptions of the "democratic" critiques.

David Mednicoff's essay, which compares the ways human rights norms are incorporated within the United States legal system with the approach taken within certain Arab states, implicitly responds to the assumption held by some that liberal "democratic" states worry more about international law because they take it more seriously or "comply" better with it. Mednicoff's work, like some of my own, challenges the premise that democratically representative nations are better international law compliers. ${ }^{16}$

Other essays in this symposium address the premise, perhaps embedded in the original call for papers, that democracies face common or generalisable "democratic" or other concerns with respect to international law. The essays here suggest, on the contrary, that liberal democratic states differ quite a bit from each other on this question. Moreover, as is most prominently suggested by the contributors from Japan, some liberal states have not experienced quite the level of "democratic" backlash evident in other quarters, such as the United States.

Teraya Koji's essay contests the premise that democracy - however construed - should be considered the ultimate desirable normative value. Teraya notes that democratic polities may produce or support some highly objectionable results - from the Nazis' to Hamas in Palestine - and that their sustenance may rely on and support authoritarian regimes elsewhere. Teraya points out that despite democracy's attempts to ameliorate tyranny by the majority, they tend to treat those that they define as "the other" or those he calls "Nobodies" - from minorities to refugees - poorly. $\mathrm{He}$ argues that international law is valuable to the extent it protects Nobodies better - even to the extent it necessarily does so undemocratically. Osamu Arakaki's essay implicitly supports this conclusion. Arakaki argues that Japan, or at least its judges (along with a complicit Diet), have not been as generous towards refugees or asylum seekers as international law demands - to the detriment of respect for such rights.

Shotaro Hamamoto's essay also defends international law against its democratic critics. His essay targets one suggested democratic "remedy" for human rights regimes: increasing parliamentary involvement. Hamamoto argues that such a remedy could end up purchasing democratic legitimacy at the expense of decreasing states' accessions to human rights instruments or

16 Compare Anne-Marie Slaughter "A Liberal Theory of International Law" (Proceedings of the $94^{\text {th }}$ Annual Meeting of the American Society of International Law, 2000) to José E Alvarez "Do Liberal States Behave Better?" (2001) 12 EJIL 183. 
their participation in individual complaints mechanisms. As do the essays by Peel and Roughan, Hamamoto defends the "democracy" accompanying international regimes on the basis of its potential to enhance democratic deliberation among distinct audiences.

As this suggests, many of the essays in this symposium do not accept the premise that international law is necessarily "undemocratic." Few of their authors accept uncritically the idea that either the international sources of law or the institutions that apply them are fundamentally flawed. The essays by the Japanese contributors in particular do not propose reforms of international rules or institutions to make them more democratic. On the contrary, to the extent that their essays criticise the status quo, the entity in the dock is either the Japanese Diet or the Japanese judiciary. The subtext of these contributions appears to be that Japan and Japanese society could use more not less international law - more recourse to custom, greater sensitivity to international rules on granting asylum, more sensitivity to the rights of other "Nobodies" under international law, and greater acceptance of individual claims procedures under human rights treaties. These essays embrace the turn to international constitutionalisation; they are not sceptical of increasing delegation to international judges. Indeed, Hamamoto concludes his essay with a wistful look at how the Europeans are changing their conception of the "demos" through an intrusive European Court of Human Rights.

There are various possible explanations for these reactions. It may be that liberal states that are still trying to secure their rightful place among international law-making institutions, including nations such as Japan whose contributions to the international law-making process remain a work in progress despite its world-power status and whose lawyers are still trying to secure the benefits of international regimes, find it premature to criticise such regimes. It may also be the case that democratic or other critiques of international regimes are simply less salient in countries where their impact has yet to be felt on the lives of ordinary citizens - as where national courts are only now starting to engage in "transnational" judicial discourse.

It may also be that a liberal state whose democracy has been fashioned, at least in part by hegemonic intervention after WWII, may also be a bit skeptical - as Teraya's essay suggests - of arrogant "democratic" critiques that presume, all too quickly, that the democracies of the West, which in the past have so often trampled on the rights of "the other" (and appear to be continuing to do so, at least with respect to refugees or, as with the United States, with respect to alleged terrorists) should be entitled to set the normative standards for the international rule of law. As Teraya also suggests, a view of democracy's virtues that cares more for achieving the fulfillment of substantive individual rights than for securing the rights of the majority may be far more willing to recognise the relative merits of international law-making mechanisms.

More generally, the essays in this symposium suggest a continuing need for what David Mednicoff calls the "comparative study of international law." This symposium - with its narrow focus on the difficulties that some liberal states face with respect to joining in or complying with international rules - will hopefully be only the opening act of future scholarly exchanges devoted to 
examining how all states - and not only "democratic" ones - incorporate international law into their own law and national institutions, including (but not limited to) courts.

Future symposia on comparative international law might begin by identifying the many reasons why even democratic states differ among themselves with respect to the vertical, horizontal and ideological critiques surveyed here. Here are a dozen possible reasons, many of which are suggested by the essays in this symposium:

(1) Because of differing constitutional or other mechanisms for acceding to treaties. It is one thing when treaties, as in case of United States trade agreements, are subject to majority vote in both houses of Congress as well as Presidential approval - just like any United States statute. It is quite another when they are, as are thousands of executive agreements entered into by the United States, subject to only Presidential approval and scrutiny. Quite apart from formal processes for parliamentary approval, democracies differ on whether parliamentary or other legislative leaders are consulted in the course of treaty negotiations, included in treaty delegations, or given options apart from a critical yes or no vote on the treaty within a narrow time frame.

(2) Because the domestic legal status of treaties differs. As some of the essays in this symposium highlight, democracies differ with respect to the relative formal status of treaties (vis-à-vis the constitution, ordinary statutes or for federal states, vis-à-vis state or provincial laws or state constitutions). They also differ with respect to ongoing congressional or parliamentary role in implementation or delegate implementation to the executive or administrative agencies. (As Harrington's essay indicates, not all democratic constitutions are as generous to international law as is article 39(1) of the South African Constitution.) Quite apart from what democratic constitutions say, democracies differ also with respect to informal practices - such as whether their parliaments or legislatures routinely choose to implement treaties (and, of course, as Harrington's essay indicates, in how they do so). The terms "monism" and "dualism" vastly over-simply the realities of modern democracies which vary greatly not only in whether all or some treaties will be treated as self-executing, but on what "self-execution" means as well as which entities (or persons) are entitled to invoke its benefits in court.

(3) Because the domestic legal status of customary law differs. As with respect to treaties, the relative impact of custom varies greatly as among democracies. As some of the essays here indicate, democracies differ on whether the three branches of government are subject to the rules of custom or are entitled to give it effect. While the United States Constitution does not, as is well known, make custom (unlike treaties) the "law of the land," some United States judicial decisions (and some statutes) have accorded it the status of federal law, with uncertain and controversial results, including with respect to its applicability to the President or administrative agencies. 
(4) Because of differences between parliamentary and other forms of democratic governance or differing traditions with respect to "separation of powers."

(5) Because of differing traditions with respect to the role of the national judiciary. Regardless of the formal legal provisions on the incorporation of international law, national judges defer on whether they will refer to or even rely on international law, treaty or customary, and democratic societies differ on whether, should they do so, domestic constituencies will object. Not all of our societies' judges see themselves as Melissa Waters' "internalisers" of international human rights and not all democratic polities would find this equally objectionable. Our judges' attitudes may defer in part depending on whether they are appointed or elected. (In the United States, as between the federal and state judiciaries they are both.) (And, as Harrington's essay reminds us, even those national judges who appear to be sympathetic to international law may be quite selective about which international law precedents they choose to cite.)

(6) Because of differing levels of government involvement in current international regimes, including through alternatives to traditional forms of international regulation such as transnational networks or extraterritorial application of national law. As Neil Craik's essay in particular highlights, states engage in differing calculations as to whether to engage in international regulation through IOs or less formal channels, with varying results on the legitimacy of these respective efforts.

(7) Because of differing levels of involvement of NGOs in domestic and international forms of governance. It is not just that our societies differ with respect to their openness to participation by international civil society but also, as Affolder and Craik suggest, with respect to whether "their" NGOs participate in particular international regimes or have the resources to do so effectively. The impact on the perceived democratic deficit also differs depending on which non-state actors impact the international regimes - mining companies or environmental groups, for example - and the power such actors wield within distinct countries.

(8) Because of differences in legal culture. Even democracies may differ with respect to the relative value attached to majoritarian or representative forms of law-making (as compared to the other two versions of the "vertical" critique outlined above). ${ }^{17}$ Such distinctions in legal culture may emerge because of distinct national experiences or historical memories (such as a history of colonialism) and may be connected to differing emphases put on how legitimate law is made between common and civil law countries.

17 See, for example, Jeb Rubenfeld "The Two World Orders" (August 2003) The Wilson Quarterly 22 (arguing that the citizens of the United States and Europe differ precisely on this basis; that is, because while the United States stresses the value of representation, Europeans stress the importance of the substantive values protected under democracy), available at www.thelatinlibrary.com (accessed 25 May 2007). 
(9) Because of differing commitments to individual immutable national constitutions.

(10) Because of differing attitudes by political elites and other society leaders, including the media. In particular, the concentration of the media into a small number of hands may well affect the perceptions of particular societies about the democratic nature of international law, where an anti-international law editorial stance is pursued.

(11) Because of differences in the powers wielded by distinct states, whether political, economic, or cultural. All else being equal one would think that those democracies with the greatest ability to have their way in international law-making forums would have the least problems with those forums or their legal products. While the extraterritorial application of one's national law may be the most "democratic" form of interstate regulation, obviously states differ with respect to their relative power to successfully undertake such efforts - as they do with respect to securing treaty provisions to their liking, ability to accede to treaties, ability to influence the formation of customary law, ability to control IOs, power to evade compliance with international norms, and so on. Ironically, the hyper-power that has the greatest ability to influence international law on all of these bases, the United States, appears to evince the greatest "democratic deficit" concerns with respect to international law-making. ${ }^{18}$

(12) Because of differing levels of participation with respect to regional or other alternatives to multilateral cooperation. As Harrington's essay reminds us, democratic polities may differ in their reaction to global law and its institutions depending on whether they have become acclimated to supranational rule through participation in regional regimes. But as Jane McAdam indicates, some regional legal harmonisation efforts may come at the expense of international law. We should not presume that Europeans are invariably and across all topics more compliant with international law merely because the EU is the most advanced "supranational" institution.

\section{CONCLUSION}

Anyone listing a dozen reasons why democracies differ among themselves with respect to their perceptions of international law runs the risk of saying little more than "everything matters" when it comes to how democracies receive and perceive international law. Yet generating case studies on how each of our societies struggles with international law is no less worthwhile than Harold Jacobson's and Edith Brown Weiss's attempts to identify the factors that drive countries to comply

18 For considerations of possible reasons for United States exceptionalism, see, for example, José E Alvarez "The Closing of the American Mind" in Canadian Council on International Law, Reconciling Law, Justice and Politics, $32^{\text {nd }}$ Annual Conference, 2003, 74. 
with international environmental law. While their book, Engaging Countries, ${ }^{19}$ concluded that pretty much everything matters, comparative international law remains a useful exercise - in part because, as some of the essays here begin to address, we need to figure out whether the direct incorporation or application of international law - as opposed to relying on "equivalent" rights guaranteed by domestic law, for example - matters.

Engaging in careful comparative international law case studies is also valuable insofar as it inspires caution as we go from description to prescription. The more we become aware of our differences, the more likely we are to realise that there may not be a single sure-fire recipe for domesticating or "democraticising" international law.

19 Harold K Jacobson and Edith B Weiss Engaging Countries: Strengthening Compliance with International Environmental Accords (MIT Press, Cambridge (Mass), 1998). 